\title{
CONTRIBUTION OF LEG MUSCLE EXPLOSIVE POWER AND LEG LENGTH WITH THE RESULTS OF THE STRADDEL- STYLE HIGH JUMP IN SMA NEGERI 6 PEKANBARU
}

\author{
Jaka Sunardi ${ }^{1 *}$, Raffly Henjilito ${ }^{2}$ \\ ${ }^{1}$ Pendidikan Olahraga, Fakultas Ilmu Keolahragaan, Universitas Negeri Yogyakarta, Jl. Colombo No. 1, \\ Karangmalang, Depok, Sleman, Daerah Istimewa Yogyakarta. \\ ${ }^{2}$ Universitas Islam Riau, Jl. Kaharuddin Nst No.113, Simpang Tiga, Bukit Raya, Kota Pekanbaru, Riau. \\ *jaka_sunardi@uny.ac.id,rafflyhenjilito@edu.uir.ac.id
}

\begin{abstract}
The purpose of this study is to determine the contribution of leg muscle explosive power and leg length to the results of straddle-style high jumping at SMA Negeri 6 Pekanbaru students. This type of research is correlation. Population and sample in this study were all students of class X IPS 2, 25 people and the sample of 15 students. The instruments of this study include the leg muscle explosive test that is vertical jump, leg length test using a meter and straddle style high jump test. The data analysis technique is the correlation value test. Based on the results of the research that has been done, it can be concluded that there is a contribution of leg muscle explosive power (X1) and high jumping straddle force results in 6 Pekanbaru (Y) High School (Y) students, where rcount $=0.53$ At significant level $5 \%$ is found rtable $=0.514$, thus rcount $>$ rtable or $0.53>0.514$. There is a contribution of leg length (X2) and straddle force high jump results in 6 Pekanbaru (Y) High School students, which is found to be $r=0.53$ At a significant level of $5 \%$ found rtable $=0.514$, thus rcount $>$ rtable or $0,53>0.514$. There is a contribution of leg muscle explosive power (X1) and leg length (X2) with the high jumping result of straddle force in high school 6 Pekanbaru $(\mathrm{Y})$ high school students, which is found to be counted $=$ 0.699 At a significant level of $5 \%$ found rtable $=0.514$, thus rcount $>r$ table or $0.699>0.514$ in the strong category.
\end{abstract}

Keywords: Leg Muscle Explosion Power, Leg Length, Straddle Style High Jump.

\section{KONTRIBUSI DAYA LEDAK OTOT TUNGKAI DAN PANJANG TUNGKAI DENGAN HASIL LOMPAT TINGGI GAYA STRADDEL PADA SISWA SMA NEGERI 6 PEKANBARU}

\begin{abstract}
Abstrak
Tujuan dari penelitian ini yaitu untuk mengetahui kontribusi daya ledak otot tungkai dan panjang tungkai dengan hasil lompat tinggi gaya straddle pada siswa SMA Negeri 6 Pekanbaru. Jenis penelitian ini ialah korelasi. Populasi serta sampel pada penelitian ini adalah seluruh siswa kelas $\mathrm{X}$ IPS 2 yaitu 25 orang serta sampelnya siswa putra yang berjumlah 15 orang. Instrument penelitian ini antara lain tes daya ledak otot tungkai yaitu vertical jump, tes panjang tungkai menggunakan meteran dan tes lompat tinggi gaya straddle. Teknik analisis datanya yaitu uji nilai korelasi. Berdasarkan dari hasil penelitian yang telah di lakukan maka dapat di simpulkan bahwa terdapat kontribusi daya ledak otot tungkai $\left(\mathrm{X}_{1}\right)$ dan hasil lompat tinggi gaya straddle pada siswa SMA Negeri 6 Pekanbaru (Y), di mana di dapati $r_{\text {hitung }}=0,53$ Pada taraf signifikan 5\% didapati $r_{\text {tabel }}=0,514$, dengan demikian $r_{\text {hitung }}>$ $\mathrm{r}_{\text {tabel }}$ atau 0,53 $>0,514$. Terdapat kontribusi panjang tungkai $\left(\mathrm{X}_{2}\right)$ dan hasil lompat tinggi gaya straddle pada siswa SMA Negeri 6 pekanbaru (Y), dimana di dapati $\mathrm{r}_{\text {hitung }}=0,53$ pada taraf signifikan $5 \%$ didapati $r_{\text {tabel }}=0,514$, dengan demikian $r_{\text {hitung }}>r_{\text {tabel }}$ atau 0,53 $>0,514$. Terdapat kontribusi daya ledak otot tungkai $\left(\mathrm{X}_{1}\right)$ dan panjang tungkai $\left(\mathrm{X}_{2}\right)$ dengan hasil lompat tinggi gaya straddle pada siswa SMA Negeri 6 Pekanbaru $(Y)$, dimana di dapati $r_{\text {hitung }}=0,699$ pada taraf signifikan 5\% didapati $r_{\text {tabel }}=0,514$, dengan demikian $\mathrm{r}_{\text {hitung }}>\mathrm{r}_{\text {tabel }}$ atau 0,699 $>0,514$ dalam kategori kuat.
\end{abstract}

Kata kunci : Daya Ledak Otot Tungkai, Panjang Tungkai, Lompat Tinggi Gaya Straddle 


\section{PENDAHULUAN}

Olahraga merupakan salah satu kegiatan yang dilakukan manusia untuk mencapai kesehatan dan kondisi fisik yang bugar. Namun seiring berjalannya waktu dan perkembangan teknologi sekarang ini terjadi perubahan atau pergeseran tujuan dan fungsi seseorang melakukan aktivitas olahraga. Jika pada awalnya manusia melakukan aktivitas olahraga hanya untuk menjaga kebugaran tubuh atau kondisi fisik, namun sekarang olahraga menambah kedunia pendidikan dan perlombaan prestasi. Olahraga juga bertujuan untuk meningkatkan kualitas sumber daya manusia, sehingga pemerintah menjadikan olahraga sebagai sarana Pembangunan Nasional. Hal ini dapat dilihat dalam pasal 25 ayat 4 Undang-Undang Nomor 3 Tahun 2005 tentang sistem Keolahragaan Nasional bahwa: "Keolahragaan nasional bertujuan memelihara dan meningkatkan kesehatan dan kebugaran, prestasi, kualitas manusia. Menanamkan nilai moral dan akhlak mulia, sportivitas, disiplin, mempererat dan membina persatuan dan kesatuan bangsa, memperkokoh ketahanan nasional, serta mengangkat, harkat, martabat, dan kehormatan bangsa".

Berdasarkan dari ketentuan bahwa jelas olahraga tidak hanya sebagai pendidikan, rekreasi, dan juga kesehatan. Olahraga juga dapat di gunakan sebagai usaha yang menghasilkan bibit-bibit prestasi secara maksimal khususnya tentu di bidang olahraga. Sebab prestasi tidak hanya bisa diraih atau didapat dalam dunia pendidikan namun juga bisa dapat diraih dalam dunia olahraga. Banyak sekali terdapat keterampilan olahraga yang diajarkan dalam mata pelajaran pendidikan jasmani. Salah satunya ialah materi atletik yang merupakan induk dari hampir semua cabang olahraga pada saat ini. Untuk menentukan kualitas dan kuantitas gerak pada olahraga atletik tidak terlepas pula pada komponen gerak dasar yang mendukungnya yaitu: jalan, lari, lompat, dan lempar. Olahraga atletik merupakan salah satu cabang yang di pertandingkan atau di perlombakan yang terdiri atas nomor-nomor yaitu: jalan, lari, lompat dan lempar. Dalam kategori nomor lompat salah satunya yang di perlombakan adalah cabang atletik lompat tinggi. Dalam hal ini, lompat tinggi juga merupakan nomor atletik yang diajarkan di tingkat sekolah menengah atas dengan unsurunsur teknik dasarnya terdiri dari awalan, tumpuan, melayang di udara dan mendarat.

Lompat tinggi adalah salah satu jenis olahraga cabang atletik dimana sang peserta didik harus melakukan lompatan setinggi-tingginya melewati mistar tanpa bantuan alat dengan berbagai jenis gaya yang diperbolehkan (gaya gunting, guling sisi, guling straddle, dan flop) atau gaya baru yang tidak bertentangan dengan aturan internasional. Saputra (2001:57) menyatakan bahwa lompat tinggi adalah suatu jenis keterampilan untuk melewati mistar yang berada diantara kedua tiang, sedangkan menurut Yopi S. Chaniago (2010:10) tujuan olahraga lompat tinggi ini yaitu untuk memperoleh lompatan setinggi-tingginya saat melewati mistar tersebut dengan ketinggian tertentu. Rachmat Fadillah (2009:27) menyatakan bahwa lompat tinggi adalah salah satu nomor lompat yang bertujuan untuk melakukan lompatan yang setinggi-tingginya melewati mistar gawang dengan ketinggian yang telah ditentukan untuk memperoleh lompatan yang setinggi-tingginya, maka dibutuhkan suatu koordinasi antara awalan lari, tolakan, dan sikap badan ketika di udara. Kemudian menurut Rachmat Fadillah (2009:28) ada beberapa gaya yang di gunakan dalam melakukan lompat tinggi, gaya-gaya tersebut antara lain: gaya guling sisi (Wastern Roll), gaya guling (Straddle), dan gaya fosbury flop. Gaya guling sisi ialah gaya yang sama pada gerakan pada gaya gunting tetapi yang sedikit membedakan hanyalah pada awalannya saja. Untuk gerakan gaya fosbury flop yaitu salah faktor yang paling penting adalah lengkungan punggung yang termasuk ekstrem pada saat hendak melewati palang atau mistar. Sedangkan pada tolakan kaki itu hampir sama dengan lompat tinggi lainnya harus memiliki kekuatan dengan ayunan kedua tangan untuk membantu mengangkat seluruh badan.

Pada pelaksanaan lompat tinggi ada urutan teknik yang harus dilakukan yaitu awalan, tolakan, melayang, dan mendarat. Untuk dapat melakukan dengan baik dalam lompat tinggi, 
kemampuan motorik yang harus diperhatikan yaitu, kekuatan, daya ledak, kelenturan, koordinasi, kecepatan, keseimbangan, kelincahan dan kelenturan. Rachmat Fadillah (2009:28) menyatakan bahwa ada beberapa gaya yang di gunakan dalam melakukan lompat tinggi, gaya-gaya tersebut antara lain: gaya guling sisi (Wastern Roll), gaya guling (Straddle), dan gaya fosbury flop. Namun dalam pembahasan pada lompat tinggi tersebut hanya membahas tentang lompat tinggi gaya straddle, yaitu lompat tinggi gaya guling perut atau straddle adalah lompat tinggi yang terdiri dari awalan, tumpuan/tolakan, melayang di udara serta pendaratannya dengan cara menggulingkan badan kedepan.

Dalam lompat tinggi ada beberapa gaya yang dilakukan untuk melakukan lompatan, gaya tersebut disesuaikan dengan kemampuan dan keterampilan dari siswa itu sendiri. Berdasarkan gaya yang ada pada lompat tinggi tersebut, lompatan tinggi gaya Straddle merupakan jenis lompatan yang dilakukan secara berguling. Menurut Saputra (2005:57) menyatakan lompat tinggi gaya guling perut merupakan salah satu gaya dalam lompat tinggi dalam keadaan posisi badan telungkup untuk melewati mistar dan langsung mendarat. Pelaksanaan gaya guling perut di awali dengan gerakan awalan tolakkan atau tumpuan, sikap badan di atas mistar dan mendarat. Widya (2006:4) mengemukanan bahwa lompat tinggi gaya straddle ialah suatu gerakan mengangkat tubuh dari titik satu ketitik lain. Menurut Agung, dkk (2004: 52) lompat tinggi gaya guling atau straddle adalah salah satu jenis gaya dalam lompat tinggi yang hingga saat ini masih dipergunakan dalam perlombaan dan diajarkan di sekolah-sekolah. Sementara Roji (2007:97) mengatakan bahwa dalam melakukan kegiatan lompat tinggi gaya straddle hendaknya siswa menguasai empat teknik dasar yaitu teknik awalan, teknik tumpuan, teknik melayang, teknik mendarat. Aip Syarifudin (2002:51) mengatakan yang di maksud dengan lompat tinggi gaya straddle adalah suatu bentuk lompatan dalam usaha untuk dapat melewati rintangan atau mistar yang dipasang pada kedua tiang dan pelompat menggunakan tumpuan satu kaki, dengan gaya straddle, lalu kaki yang lain langsung kearah mendarat dan diikuti oleh bagian badan yang lain.

Mencapai lompatan yang setinggi-tingginya bukan merupakan hal yang mudah dalam lompat tinggi gaya Straddle. Untuk bisa melakukan lompat yang tinggi untuk melewati mistar dibutuhkan penguasaan teknik lompat tinggi gaya Straddle yang baik dan benar. Jess Jarver (2009:52) menyatakan, gerakan dalam lompat tinggi dibagi dalam beberapa tahap yang terpisah, yaitu tahap lari, tahap take off, dan tahap melompati mistar. Menurut Yopi S. Chaniago (2010:18-19) cara melakukan gaya guling perut terdiri dari : Awalan yaitu biasanya awalan lompat tinggi gaya guling perut (Straddle) mengambil awalan dari samping dengan jarak antara 3 sampai 9 meter/langkah. Hal ini bergantung pada ketinggian mistar, semakin tinggi ukuran mistar akan semakin jauh awalannya. Biasanya awalan dilakukan dengan lankah ganjil. Pada langkah terakhir, diusahakan gerakan langkah yang lebar. Tumpuan/tolakan yaitu kaki tolak didorong ke depan dengan kuat, ke depan tumit. Dengan demikian, pinggang akan maju ke depan sehingga badan agak melenting ke belakang. Sementara itu, lengan berada jauh di belakang. Dari sinilah mulai gerakan mengangkat, yaitu titik dari berat badan melewati atas kaki penolak. Kaki ayun yang sedikit bengkok bergerak ke depan kaki tolak dan ayunkan ke atas dengan kuat. Untuk membantu gerakan menolak yang dilakukan oleh salah satu kaki, kedua lengan diayunkan ke atas. Melayang yaitu setelah kaki yang diayunkan itu melewati mistar, balikkan badan secepatnya sehingga terlungkup di atas mistar. Usahakan letak pinggul lebih tinggi dari pada pundak dan miringkan kepala ke bawah mistar. Kaki untuk gerakan melompat di lipat kesamping dengan cepat dan di gerakkan ke atas sehingga membalik dengan cepat. Mendarat yaitu pada waktu mendarat atau jatuh yang pertama kali menyentuh matras adalah kaki kanan dan tangan kanan bila tumpuan menggunakan kaki kiri, lalu berguling. Cara bergulingnya yaitu menggulingkan badan ke depan atau menyusurkan punggung tangan ke depan dan berakhir pada bahu sebelah kanan. Gerakan ini harus di lakukan dengan cepat. 
Daya ledak otot tungkai termasuk vital dalam olahraga atletik lompat tinggi. Hal ini cukup beralasan karena daya ledak otot tungkai sangat membantu dalam prosesnya untuk mencapai dan menciptakan hasil lompat tinggi. Daya ledak otot tungkai juga merupakan bagian dari kesempurnaan lompat tinggi karena kemampuan otot saat melakukan aktivitas atau gerakan kerja yang cepat dan dalam waktu yang singkat. Daya ledak ialah kemampuan sebuah otot atau sekelompok otot untuk mengatasi tahanan beban dengan kekuatan dan kecepatan tinggi dalam suatu gerakan yang utuh. Daya ledak merupakan kemampuan seseorang untuk mendapatkan kekuatan maksimal dengan waktu secepat-cepatnya (Lesmana \& Nasrulloh, 2020). Daya ledak otot tungkai sangat di perlukan, karena seseorang yang hendak melompat maka salah satu aspek yang perlu di perhatikan adalah masalah daya ledak otot tungkai. Menurut Ismaryati (2008:59) daya ledak yaitu menyangkut kekuatan dan kecepatan kontraksi otot yang dinamis dan eksplosif serta melibatkan pengeluaran kekuatan otot yang maksimal dalam waktu yang secepat-cepatnya. Menurut Syafruddin (2011:72) daya ledak adalah terjemahan dari kata explosive power atau power dalam bahasa Inggris dan juga schnelkraft dalam bahasa Jerman. Menurut Sukadiyanto dalam Apta \& Febi (2015:136) power merupakan hasil kali antara kekuatan dan kecepatan. Menurut Yoda (2006: 27) power adalah kemampuan otot untuk mengerahkan kekuatan yang maksimal dalam waktu yang sangat cepat. Sedangkan menurut Sajoto dalam Jasrizal Saputra (2016:7) power merupakan suatu kekuatan yang di pengaruhi oleh kekuatan dan kecepatan.

Untuk membantu lompatan dan pada saat melakukan awalan dalam olahraga atletik lompat tinggi, faktor panjang tungkai juga berpengaruh pada hasil lompatan. Panjang tungkai memiliki ayunan yang lebih jauh atau panjang sehingga membantu pencapaian lompatan yang maksimal sehingga dapat membantu siswa pada saat melewati mistar ketika hendak melakukan lompatan. Setiap cabang olahraga menuntut syarat-syarat khusus agar mampu meraih prestasi secara maksimal. Demikian halnya dengan seorang atlet lompat harus memiliki tubuh yang tinggi dan atletis di sertai dengan otot- otot yang kuat. Postur tubuh yang tinggi biasanya di sertai segmen tubuh yang panjang baik lengan maupun tungkainya. Di tinjau dari biomekanika bahwa tungkai yang panjang memiliki jangkauan yang jauh atau panjang. Maka tungkai yang panjang memiliki ayunan yang lebih jauh atau panjang sehingga membantu pencapaian lompatan yang maksimal. Untuk mencapai prestasi yang maksimal dalam lompat tinggi, maka panjang tungkai harus di manfaatkan pada teknik yang benar. Menurut Drajad Hadi (2013:25) bahwa panjang tungkai melibatkan tulang dan otot pembentuk tungkai, baik tungkai bawah dan tungkai atas di sertai tulang yang membentuk tungkai yaitu tulang-tulang kaki, tulang tibia dan fibula, tulang femur. Menurut Suharno dalam Irma (2018:24) panjang tungkai adalah jarak vertikal antara telapak kaki sampai dengan pangkal paha yang di ukur dengan cara berdiri tegak. Menurut Sukri Frisal (2016:11) menyatakan otot tungkai meupakan kemampuan otot untuk mengatasi beban dengan kecepatan kontraksi yang sangat tinggi. Sedangkan menurut Supriono (2015:10) menyatakan bahwa otot tungkai merupakan jaringan otot yang terdapat atau berada pada daerah tungkai.

Berdasarkan dari hasil observasi, peneliti melihat ada yang belum bisa atau masih banyak melakukan kesalahan dalam melakukan lompat tinggi, karena hal ini dipengaruhi oleh faktor teknik dasar dan juga faktor kondisi fisik siswa sehingga berdampak dengan hasil lompatan yang kurang memuaskan. Faktor kondisi fisik yang disebut ialah faktor daya ledak dan kekuatan otot tungkai serta tinggi badan atau panjang tungkai. Daya ledak otot tungkai pada saat siswa melakukan lompatan melewati mistar masih banyak yang lemah dikarenakan tidak jarang siswa memilih kaki tumpuan yang salah atau bahkan ada langsung menabrak mistar. Peneliti juga melihat tinggi badan dan panjang tungkai siswa yang masih kurang, sehingga badan dan tungkainya sejajar dengan mistar yang mengakibatkan badan dan tungkainya tidak cukup sampai melewati mistar maka berdampak dengan siswa menjatuhkan mistar saat melakukan lompatan tersebut. Berdasarkan dari latar belakang di atas tersebut, 
peneliti tertarik untuk melakukan studi penelitian Pada Siswa SMA Negeri 6 Pekanbaru dengan judul: Kontribusi Daya Ledak Otot Tungkai Dan Panjang Tungkai Dengan Hasil Lompat Tinggi Gaya Straddel Pada Siswa SMA Negeri 6 Pekanbaru.

\section{METODE}

Penelitian ini tergolong ke dalam jenis penelitian dengan tenik korelasional. dalam penelitian ini penulis ingin mengetahui kontribusi antara dua variabel yang akan dikaitkan, yakni variabel bebas dan variabel terikat. Adapun variabel bebas $\left(\mathrm{X}_{1}\right)$ dan $\left(\mathrm{X}_{2}\right)$ dalam penelitian ini daya ledak otot tungkai dan panjang tungkai, sedangkan variabel terikatnya $(\mathrm{Y})$ yaitu hasil lompat tinggi gaya straddle. Adapaun desain penelitian ini menurut Martiani (2014:23) maka dapat digambarkan daya ledak otot tungkai $\left(\mathrm{X}_{1}\right)$ dan panjang tungkai $\left(\mathrm{X}_{2}\right)$ dengan hasil lompat tinggi gaya straddle $(\mathrm{Y})$, sebagai berikut :

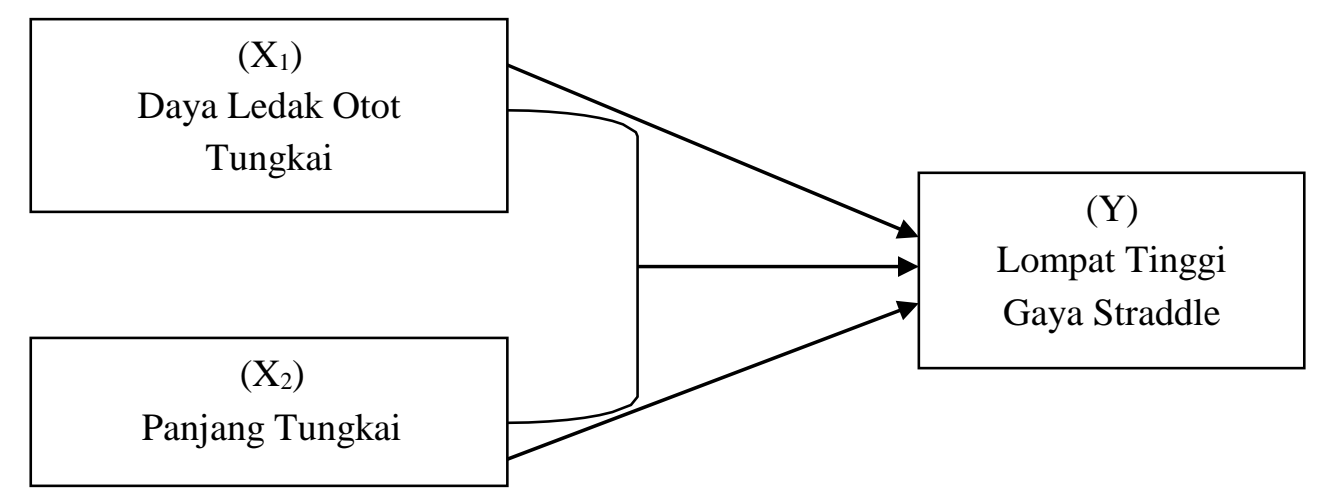

Gambar 1. Desain Penelitian

Martiani (2014:23)

Populasi yang tedapat dalam penelitian ini adalah seluruh siswa kelas X IPS 2 di SMA Negeri 6 Pekanbaru yang berjumlah 25 orang siswa. Di dalam penelitian ini, peneliti menggunakan teknik penarikan sampel yaitu Purposive Sample yang berarti peneliti mengambil subjek atas di dasarkan adanya tujuan tertentu. Sample penelitiannya adalah siswa putra yang berjumlah 15 orang di kelas X IPS 2 SMA Negeri 6 Pekanbaru. Adapun instrumen penelitian ini terdiri dari bermacam tes yaitu tes daya ledak otot tungkai dengan Vertical Power Jump, tes panjang tungkai serta tes lompat tinggi gaya straddle.

Teknik analisis data yang akan di gunakan dalam penelitian ini sebagai berikut: 1) Untuk melihat kontribusi daya ledak otot tungkai $\left(\mathrm{X}_{1}\right)$ dengan hasil lompat tinggi gaya straddle (Y) yaitu menggunakan korelasi sederhana dengan rumus Pearson. 2) Untuk melihat kontribusi panjang tungkai $\left(\mathrm{X}_{2}\right)$ dengan hasil lompat tinggi gaya straddle ( $\mathrm{Y}$ ) yaitu menggunakan korelasi sederhana dengan rumus Pearson, 3) Untuk melihat kontribusi daya ledak otot tungkai $\left(\mathrm{X}_{1}\right)$ dan panjang tungkai $\left(\mathrm{X}_{2}\right)$ yaitu menggunakan korelasi sederhana dengan rumus Pearson, 4) Untuk melihat kontribusi daya ledak otot tungkai $\left(\mathrm{X}_{1}\right)$ dan panjang tungkai $\left(\mathrm{X}_{2}\right)$ dengan hasil lompat tinggi gaya straddle $(\mathrm{Y})$ yaitu menggunakan korelasi ganda, 5) Untuk melihat besarnya Kontribusi daya ledak otot tungkai dan panjang tungkai dengan hasil lompat tinggi gaya straddle pada siswa di SMA Negeri 6 Pekanbaru dengan melihat koefisien determinasi menurut Sugiyono (2010:215) dengan rumus: $K D=r^{2}$ x 100

\section{HASIL DAN PEMBAHASAN}

Dalam penelitian ini membahas tentang kontribusi daya ledak otot tungkai dan panjang tungkai dengan hasil lompat tinggi gaya straddle pada siswa SMA Negeri 6 Pekanbaru. 
Deskripsi hasil penelitian data distribusi frekuensi daya ledak otot tungkai vertical jump pada siswa SMA Negeri 6 Pekanbaru dapat dilihat dari tabel di bawah ini :

Tabel 1. Distribusi Frekuensi Daya Ledak Otot Tungkai Vertical Jump pada Siswa SMA Negeri 6 Pekanbaru

\begin{tabular}{|c|c|c|c|}
\hline No & Interval & Frekuensi Absolut & Frekuensi Relatif \\
\hline 1 & $40-43$ & 2 & $13,33 \%$ \\
\hline 2 & $44-47$ & 2 & $13,33 \%$ \\
\hline 3 & $48-51$ & 5 & $33,33 \%$ \\
\hline 4 & $52-55$ & 3 & $20,00 \%$ \\
\hline 5 & $56-60$ & 3 & $20,00 \%$ \\
\hline \multicolumn{2}{|r}{ Jumlah } & $\mathbf{1 5}$ & $\mathbf{1 0 0 \%}$ \\
\hline
\end{tabular}

Deskripsi hasil penelitian distribusi frekuensi data hasil tes panjang tungkai pada siswa SMA Negeri 6 Pekanbaru dapat dilihat dari tabel di bawah ini :

Tabel 2. Distribusi Frekuensi Data Hasil Tes Panjang Tungkai pada Siswa SMA Negeri 6 Pekanbaru

\begin{tabular}{|c|c|c|c|}
\hline No & Interval & Frekuensi Absolut & Frekuensi Relatif \\
\hline 1 & $80-83$ & 2 & $13,33 \%$ \\
\hline 2 & $84-87$ & 0 & $0,00 \%$ \\
\hline 3 & $88-91$ & 1 & $6,67 \%$ \\
\hline 4 & $92-95$ & 6 & $40,00 \%$ \\
\hline 5 & $96-100$ & 6 & $40,00 \%$ \\
\hline \multicolumn{2}{|c}{ Jumlah } & $\mathbf{1 5}$ & $\mathbf{1 0 0 \%}$ \\
\hline
\end{tabular}

Deskripsi hasil penelitian tentang distribusi frekuensi data hasil tes lompat tinggi gaya straddle pada siswa SMA Negeri 6 Pekanbaru dapat dilihat dari tabel di bawah ini :

Table 3. Distribusi Frekuensi Data Hasil Tes Lompat Tinggi Gaya Straddle pada Siswa SMA Negeri 6 Pekanbaru

\begin{tabular}{|c|c|c|c|}
\hline No & Interval & Frekuensi Absolut & Frekuensi Relatif \\
\hline 1 & $100-101$ & 5 & $33,33 \%$ \\
\hline 2 & $102-103$ & 0 & $0,00 \%$ \\
\hline 3 & $104-105$ & 4 & $26,67 \%$ \\
\hline 4 & $106-107$ & 0 & $0,00 \%$ \\
\hline 5 & $108-110$ & 6 & $40,00 \%$ \\
\hline \multicolumn{2}{|c|}{ Jumlah } & $\mathbf{1 5}$ & $\mathbf{1 0 0} \%$ \\
\hline
\end{tabular}

Data yang telah terkumpul kemudian di analisis. Yang menjadi variabel $\mathrm{X}_{1}$ adalah daya ledak otot tungkai dan yang menjadi variabel $\mathrm{X}_{2}$ adalah panjang tungkai serta yang menjadi variable $\mathrm{Y}$ adalah hasil lompat tinggi gaya straddle. Adapun hipotesis yang akan di uji ialah : terdapat kontribusi daya ledak otot tungkai dan panjang tungkai dengan hasil lompat tinggi gaya straddle pada siswa SMA Negeri 6 Pekanbru. Dengan kaidah pengujian sebagai berikut: Jika $\mathrm{r}_{\text {hitung }}>\mathrm{r}_{\text {tabel }}$ maka signifikan Jika $\mathrm{r}_{\text {hitung }}<\mathrm{r}_{\text {table }}$ maka tidak signifikan.

Dari hasil perhitungan dapat di ketahui bahwa besar nilai korelasi antara daya ledak otot tungkai dan panjang tungkai dengan hasil lompat tinggi gaya straddle pada siswa SMA Negeri 6 Pekanbaru adalah 0,699 yang termasuk ke dalam kategori kuat. Setelah angka korelasinya di dapat, selanjutnya di lakukan pengujian hipotesis yaitu : terdapat kontribusi daya ledak otot tungkai $\left(\mathrm{X}_{1}\right)$ dan hasil lompat tinggi gaya straddle pada siswa SMA Negeri 6 pekanbaru $(\mathrm{Y})$, dimana di dapati rhitung $=0,53$ Pada taraf signifikan 5\% di dapati rtabel $=0,514$, dengan 
demikian rhitung $>$ rtabel atau 0,53 >0,514. Juga terdapat kontribusi panjang tungkai (X2) dan hasil lompat tinggi gaya straddle pada siswa SMA Negeri 6 Pekanbaru (Y), dimana di dapati $r_{\text {hitung }}=0,53$ Pada taraf signifikan 5\% di dapati $r_{\text {tabel }}=0,514$, dengan demikian $r_{\text {hitung }}>$ $\mathrm{r}_{\text {tabel }}$ atau $0,53>0,514$. Kemudian terdapat kontribusi daya ledak otot tungkai $\left(\mathrm{X}_{1}\right)$ dan panjang tungkai $\left(\mathrm{X}_{2}\right)$ dengan hasil lompat tinggi gaya straddle pada siswa SMA Negeri 6 pekanbaru (Y), dimana di dapati rhitung $=0,699$ Pada taraf signifikan 5\% didapati rtabel $=0,514$, dengan demikian rhitung $>$ rtabel atau 0,699 >0,514. Hal ini menunjukan adanya korelasi atau hubungan antara variable $\mathrm{X} 1$ dan $\mathrm{X} 2$ dan juga variabel $\mathrm{Y}$ sehingga secara otomatis akan ada nilai kontribusinya.

Nilai kontribusi dari daya ledak otot tungkai dan panjang tungkai dengan hasil lompat tinggi gaya straddle pada siswa SMA Negeri 6 Pekanbaru di hitung dengan menggunakan rumus : $\mathrm{KD}=\mathrm{r}^{2} \times 100 \%$. Dimana $\mathrm{r}$ merupakan angka korelasi yaitu 0,699 sehingga $\mathrm{KD}=$ $0,6992 \times 100 \%=48,86 \%$ yang berarti bahwa saat siswa melakukan lompat tinggi gaya straddle melewati tiang atau mistar, maka daya ledak otot tungkai dan panjang tungkainya memberikan kontribusi sebesar 48,86\%.

Dari analisis data yang telah di kemukakan di ketahui adanya hubungan yang signifikan antara kontribusi dari daya ledak otot tungkai dan panjang tungkai dengan hasil lompat tinggi gaya straddle pada siswa SMA Negeri 6 Pekanbaru. Daya ledak otot tungkai dan panjang tungkai berkontraksi dengan cepat dan kuat sehingga memberikan momentum untuk memudahkan melakukan lompatan yang tinggi, dengan demikian untuk menghasilkan kecepatan dan kekuatan lompatan yang tinggi di perlukan daya ledak otot tungkai serta panjang tungkai.

Adanya kontribusi dari $\mathrm{X}_{1}$ daya ledak otot tungkai dan $\mathrm{X}_{2}$ panjang tungkai terhadap $\mathrm{Y}$ hasil lompat tinggi gaya straddle yang akan di capai oleh seorang siswa akan menjadi lebih bagus apabila ia memiliki daya ledak otot tungkai dan panjang tungkai yang baik. Karena dengan daya ledak otot tungkai dan panjang tungkai tersebut siswa tersebut akan dapat melakukan lompatan yang tinggi yang dapat melewati mistar. Dari hal ini peneliti menemukan berdasarkan hasil pengolahan data bahwa daya ledak otot tungkai dan panjang tungkai memberikan kontribusi sebesar $48,86 \%$. Untuk sisanya yaitu sebesar $51,14 \%$ di pengaruhi oleh faktor lain seperti, ketepatan melangkah serta time atau waktu saat hendak melompat dan jarak saat melompat dengan mistar harus tepat. Dengan ketepatan melangkah serta time atau waktu saat hendak melompat dan jarak saat melompat dengan mistar harus tepat maka akan meraih lompatan yang di inginkan atau maksimal.

Dari keterangan di atas dapat pahami bahwa ketepatan melangkah serta time atau waktu saat hendak melompat dan jarak saat melompat dengan mistar harus tepat. Dengan ketepatan melangkah serta time atau waktu saat hendak melompat dan jarak saat melompat dengan mistar harus tepat maka akan meraih lompatan yang di inginkan atau maksimal.

Dari uraian tersebut jelaslah bahwa untuk menghasilkan lompat tinggi gaya straddle yang baik di perlukan daya ledak otot tungkai dan panjang tungkai yang maksimal dan juga faktor lainnya yang mendukung ketepatan melangkah serta time atau waktu saat hendak melompat dan jarak saat melompat dengan mistar harus tepat.

Hasil penelitian ini relevan dengan penelitan Raffly Henjilito (2019:104) bahwa penelitiannya tersebut berhasil membuktikan hipotesis yang berbunyi kontribusi daya ledak otot tungkai terhadap kecepatan lari jarak pendek 100 meter menghasilkan nilai t hitung lebih tinggi $(0,659)$ dibandingkan dengan $t$ tabel $(0,576)$ pada level significance $5 \%$, Maka dapat ditarik kesimpulan bahwa terdapat hubungan yang signifikan antara daya ledak otot tungkai dengan kecepatan lari jarak pendek 100 meter, Dengan demikian daya ledak otot tungkai sangat berkontribusi terhadap kecepatan lari jarak pendek 100 meter.

Hasil penelitian ini juga relevan dengan penelitannya Muchamad Samsul Huda (2011:36) bahwa penelitiannya tersebut berhasil membuktikan hipotesis yang berbunyi ada 
hubungan yang signifikan daya ledak tungkai dan panjang tungkai dengan kemampuan lompat jauh siswa SMP Negeri 02 Samarinda, Hipotesis Statistik yang akan diuji: Ho : $\mathrm{Rx}_{1}, 2 \mathrm{y}$ $=0, \mathrm{H}_{1}: \mathrm{Rx}_{1}, 2 \mathrm{y} \neq 0$, Hasil pengujian: Dari analisis data di peroleh nilai korelasi ganda, di peroleh nilai $\mathrm{R}$ hitung $(\mathrm{Ro})=.664(\mathrm{P}<0.05)$, maka Ho ditolak dan $\mathrm{H}_{1}$ diterima. Hal ini berarti ada hubungan yang signifikan antara daya ledak tungkai dan panjang tungkai dengan kemampuan lompat jauh siswa SMP Negeri 02 Samarinda.

Hasil penelitian ini juga relevan dengan penelitan Zulpikar Ilham (2017:20) bahwa penelitiannya tersebut berhasil membuktikan hipotesis yang berbunyi hasil yang di peroleh daya ledak otot tungkai (X) mempunyai hubungan signifikan dengan hasil lompat tinggi (Y) siswa SMK YPS Prabumulih, ditandai dengan hasil yang diperoleh yaitu thitung7,291 sedangkan ttabel pada taraf signifikan $=0.05$ yaitu 2,034 .

Hasil penelitian tersebut ternyata menunjukkan bahwa daya ledak otot tungkai dan panjang tungkai mempunyai hubungan nilai korelasi dengan lari sprint, lompat jauh serta lompat tinggi yang di mana hasil tersebut menjadi relevan dengan penelitian yang telah saya lakukan.

\section{SIMPULAN}

Berdasarkan dari hasil penelitian yang telah di lakukan maka dapat di simpulkan : 1) Terdapat kontribusi daya ledak otot tungkai $\left(\mathrm{X}_{1}\right)$ dan hasil lompat tinggi gaya straddle pada siswa SMA Negeri 6 pekanbaru (Y), 2) Terdapat kontribusi panjang tungkai $\left(\mathrm{X}_{2}\right)$ dan hasil lompat tinggi gaya straddle pada siswa SMA Negeri 6 pekanbaru (Y), 3) Terdapat kontribusi daya ledak otot tungkai $\left(\mathrm{X}_{1}\right)$ dan panjang tungkai $\left(\mathrm{X}_{2}\right)$ dengan hasil lompat tinggi gaya straddle pada siswa SMA Negeri 6 pekanbaru (Y).

Dari hal ini peneliti menemukan berdasarkan hasil pengolahan data bahwa daya ledak otot tungkai dan panjang tungkai memberikan kontribusi sebesar 48,86\%. Untuk sisanya yaitu sebesar $51,14 \%$ di pengaruhi oleh faktor lain seperti, ketepatan melangkah serta time atau waktu saat hendak melompat dan jarak saat melompat dengan mistar harus tepat. Dengan ketepatan melangkah serta time atau waktu saat hendak melompat dan jarak saat melompat dengan mistar harus tepat maka akan meraih lompatan yang di inginkan atau maksimal.

\section{DAFTAR PUSTAKA}

Chaniago, Y.S. (2010). Lompat Tinggi. Boyolali: Hamudha Prima Media. Fadhillah, R. (2009). Kenapa Atletik Disebut Induk Semua Cabang Olahraga ?. Jakarta Selatan: Buana Cipta Pustaka.

Frisal, S. (2016).Kontribusi Daya Ledak Otot Tungkai Terhadap Hasil Lompat Jangkit Pada Siswa Ma Hasanah Pekanbaru. Disertasi. Universitas Islam Riau.

Henjilito, R. (2019). Hubungan Daya Ledak Otot Tungkai Dengan Kecepatan Lari Jarak Pendek 100 Meter. JurnalOlahraga, 4(2), 104.

Huda, M.S. (2011). Hubungan Antara Daya Ledak Tungkai Dan Panjang Tungkai Dengan Kemampuan Lompat Jauh Pada Siswa Smp Negeri 02 Samarinda. Jurnal ILARA. II(1), 32-38.

Ilham, Z. (2017). Hubungan Antara Daya Ledak Otot Tungkai Dengan Hasil Lompat Tinggi Gaya Straddle Siswa Putra Kelas X SmkYps Prabumulih. Jurnal Ilmu Keolahragaan, 16(1), 12-21.

Lesmana, G I, Nasrulloh A. (2020). Efektivitas Kinesio Tape terhadap Kemampuan Daya Ledak Otot Tungkai Pemain Basket Amatir. Medikora. Vol. 19 No. 2 Oktober 2020, Hal 61-70 
MEDIKORA, Vol. 19 No. 2 Oktober 2020 - 149

Jaka Sunardi, Raffly Henjilito

Martiani. (2014). Kontribusi Kekuatan Otot Lengan Dan Kekuatan Otot Punggung Terhadap Kemampuan Bantingan Pinggang Dalam Olahraga Gulat Atlet Pengda Pgsi Provinsi Bengkulu. Disertasi. Universitas Bengkulu.

Saputra, J. (2016). Kontribusi Daya Ledak Otot Tungkai Terhadap Hasil Lompat Tinggi Pada Siswa Putra Kelas XI IPS 2 SMA Negeri 14 Pekanbaru. Disertasi. Universitas Islam Riau.

Supriono. (2015). Kontribusi Daya Ledak Otot Tungkai Terhadap Kemampuan Tendangan Depan Siswa Ekstrakulikuler Pencak Silatlks Pi Kera Sakti Smp N 5 Kandis Kabupaten Siak. Disertasi. Universitas Islam Riau.

Syafruddin. (2011).Ilmu Kepelatihan Olahraga. Padang: UNP Press. 